International Journal of Social Sciences and Humanities
Available online at http://sciencescholar.us/journal/index.php/ijssh
Vol. 2 No. 2, August 2018, pages: $187 \sim 193$
e-ISSN: 2550-7001, p-ISSN: 2550-701X
https://doi.org/10.29332/ijssh.v2n2.163

\title{
Multimedia Use and Learning Styles on Learning Achievement in Social Studies
}

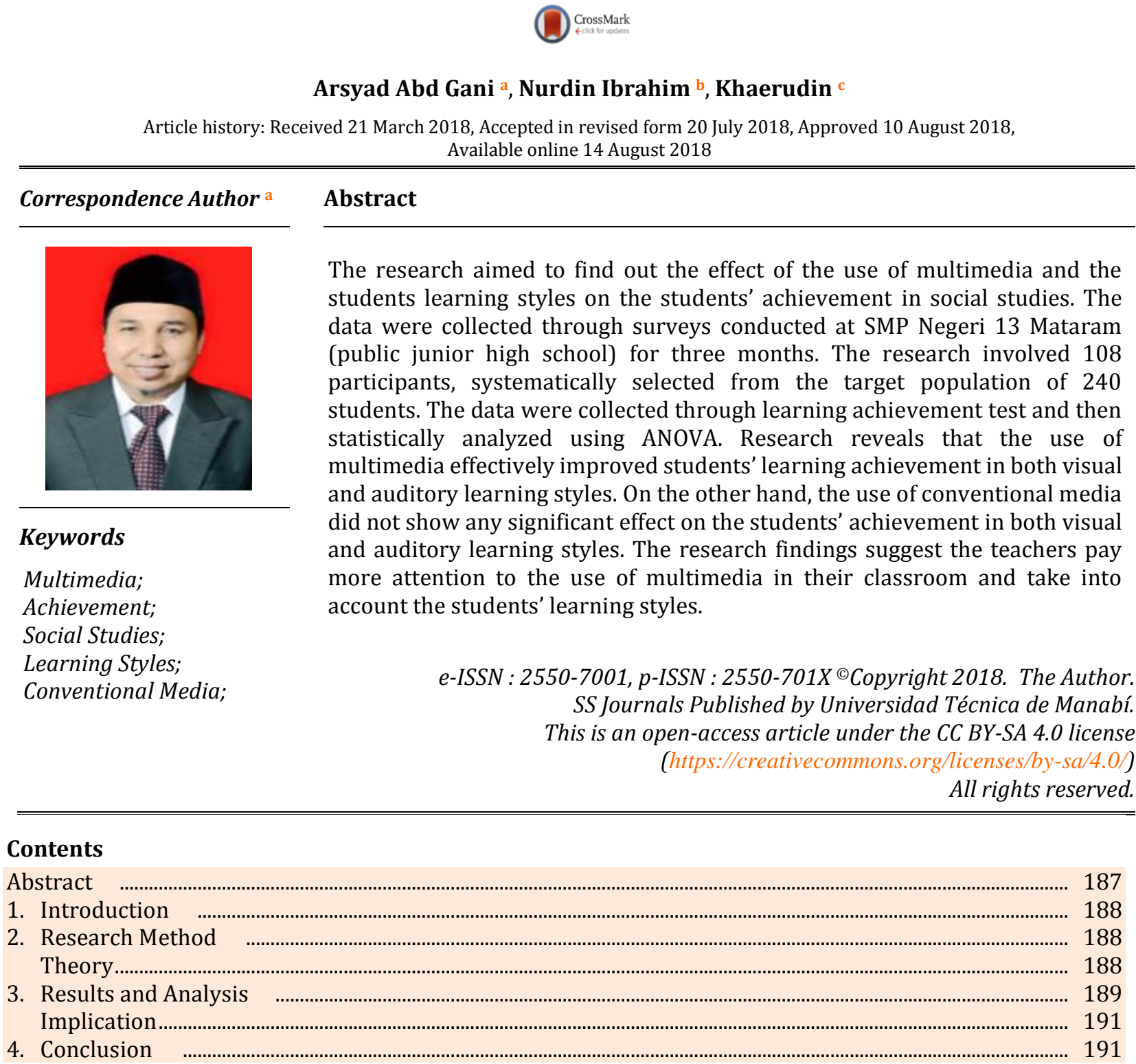

a Doctoral student at Jakarta State of University, Indonesia

b Lecturer at Jakarta State of University, Indonesia

c Lecturer at Jakarta State of University, Indonesia 
Conflict of interest statement and funding sources........................................................................................ 191

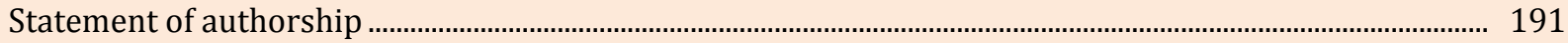

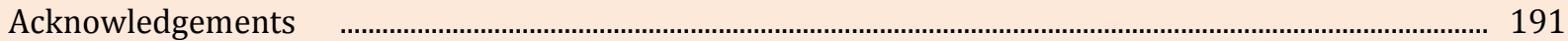

References

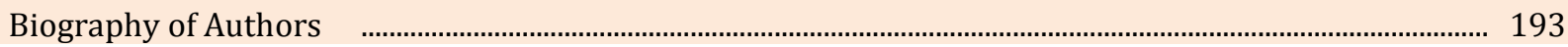

\section{Introduction}

Every child is endowed with different characteristics and brain capacities in absorbing, processing, and conveying information; thus, they are different in learning capacity. Learning constitutes mental activities that involve brain capacity in processing information. Learning is not merely memorizing facts but also processing different types of information and using them for varying purposes. In order for the learners to retain the information stored in their memory, they have to process and understand it well. The way they learn is influenced by both internal and external factors such as their learning styles and media they use to help them learn.

One of the learners' characteristics that relate to information processing is their learning styles. Learners with visual learning style learn very quickly by seeing others doing something or looking at how things are processed. These learners like systematic ways of providing information but dislike writing what teachers say or instruct. Contrast to this type of learners, auditory learners rely heavily on their hearing ability, while kinesthetic learners prefer direct involvement in a particular activity.

This research aimed at exploring the different learning achievements on social studies between students with visual learning style and those with auditory style related to the use of multimedia in the classrooms.

\section{Research Method}

This research used the quantitative method. It was conducted at SMP Negeri 13 Mataram from October 2016 to December 2016. Participants consisted of 224 students at grade eighth with visual learning type; 30 students were taken for instrument test. Research sample taken using random sampling technique consisted of 108 students, divided into two groups with an equal number, namely experimental group, and controlling group. While students in the experimental group were provided with multimedia, the students in the controlling group were treated with conventional media.

Data for the research were collected using an instrument of learning test and a questionnaire about learning styles. Data were then analyzed using both descriptive and inferential statistics. Inferential statistics were used for an analysis related to data normality, homogeneity, and multivariate statistics. Hypothesis testing in this research was conducted through F-test continued with post-hoc or Tukey-Test.

Theory

Related to different styles of learners, Siberman (2014) reports that in every 30 students, 22 of them can learn effectively during which the teacher presents an activity that combines visual, auditory, and kinesthetic senses. The rest of the children prefer one of those three styles, and as a result, they struggle to learn the lesson, which is not well structured to support learner's particular style.

Teachers and scholars have paid great attention to the children hereditary condition with varying characteristics. The hereditary background is believed to have an impact on the child's ability to hear, see, and move physically; thus, it contributes to the child's ability to learn. The availability of proper media can attract learners' attention, trigger their intake capacity, and strengthen their capacity to store information in their memory.

Research by Lim, Zhao, Thonder, and Thai (2013) showed that the adaptation of technological application at school is influenced and constrained by a number of factors including the condition of technological resources, school culture, experience and readiness of teachers and students in using technology, and the dynamics of social interactions within the school system. 
In accordance with the aforementioned research, Sanisah (2013) reported that teachers in Mataram City often face difficulties in selecting and using learning media, appropriate methods and strategies, discussing particular teaching materials, and delivering methods that mostly attract the students. Consequently, they face difficulties in creating active, innovative, creative, educative, joyful, delightful, and quality learning. In her research on the use of media by 100 social studies teachers in Mataram, Sanisah reported that (1) 55\% of the teachers use media in their teaching, (2) 23\% of teachers have made a medium (teachers made media), (3) 97\% make use of media available at school (ready-made media), (4) 12\% teachers use video and television (audiovisual media), and (5) 9\% teachers use computer and LCD projector (Sanisah, 2013, pp. 33-39).

Similarly, preliminary research conducted by one of our team in a number of junior secondary schools in Mataram shows a similar result. Social studies teachers are frequently encountered with barriers in delivering lessons and selecting media. As a subject matter, social studies are considered more complex as they comprise of sub-subjects including history, geography, and economics. This situation requires the teachers to have a comprehensive understanding of the subject matter as well as its composing elements. Considering the width and complexity of the materials taught in this subject matter, teachers are demanded to use attractive media or multimedia to avoid students' feeling of boredom.

Multimedia are products of the advancement in digital technology. These media are able to provide rich learning experiences for their users. Multimedia can present messages and knowledge in the forms of text, audio, graphics, video, and animation in a simultaneous manner. With this feature, multimedia can present extremely comprehensive information that the students need to learn.

The use of multimedia as a teaching aid can be modified according to the need and ability of the students as the users. Today, multimedia-based learning program has been integrated with the use of a computer, allowing the multimedia program to be used as an interactive program. There are a lot of strategies and methods that can be employed to design and produce a multimedia program that is effective for interactive learning media. The interactive feature of this type of media allows for more dialogic learning processes.

\section{Results and Analysis}

This experimental research with $2 \times 2$ design used two-factor analysis of variance (ANOVA). The following table presents a summary of the results.

Table 1

A summary of two-factor ANOVA with equal cells

\begin{tabular}{|c|c|c|c|c|c|c|}
\hline Source & SS & $\mathrm{dF}$ & MS & F-cal & F-tab & Solution \\
\hline Learning Media (A) & 172,79 & 1 & 172,79 & 9,06 & 3,94 & Reject $\mathrm{H} 0$ \\
\hline Learning Styles (B) & 253,72 & 1 & 253,72 & 13,31 & 3,94 & Reject HO \\
\hline Interaction $(\mathrm{AxB})$ & 83,25 & 1 & 83,25 & 4,37 & 3,94 & Reject H0 \\
\hline Error & 1982,52 & 104 & 19,06 & - & - & - \\
\hline Total & 2492,29 & 107 & - & - & - & - \\
\hline
\end{tabular}

With reference to the above table (Table 1), average testing criteria, and interaction, some conclusions can be drawn as follow:

\section{Reject HO on Learning Media (A)}

Research reveals a difference in the effect of learning media on the group of students with multimedia and a group of students treated with conventional media on students' learning achievement. In other words, learning achievement of students treated with multimedia differs from ones with conventional media.

Gani, A. A., Ibrahim, N., \& Khaerudin, -. (2018). Multimedia use and learning styles on learning achievement in social studies. International Journal of Social Sciences and Humanities, 2(2), 187-193. https://doi.org/10.29332/ijssh.v2n2.163 
Reject HO on Learning Style (B)

Research reveals different effects on learning style between auditory students and students with visual style. In other words learning style has an effect on the difference in students' achievement.

\section{Accept $\mathrm{HO}$ on Interaction $(A B)$}

It was revealed that there is an interaction between learning media and learning styles towards learning achievement. It means that the characteristics of style difference in every learning medium are different. It also means that the difference in learning achievement resulted from each of the learning media is inconsistent with each learning style. Moreover, the different learning achievement from each learning style is inconsistent in each of the media. Therefore, the result has to be further tested using a post-hoc test.

Post-hoc test in this research uses Tukey-test for the number of data between cells is equal. Results of Tukeytest conducted are presented in the table below.

Table 2

A summary of Tukey-test

\begin{tabular}{lllll}
\hline Source & N & Q count & Q Table & Solution \\
\hline Multimedia & 27 & 5,738 & 2,902 & H0 rejected \\
Conventional & 27 & 1,558 & 2,902 & H0 accepted \\
Visual & 27 & 5,100 & 2,902 & H0 rejected \\
Auditory & 27 & 0,921 & 2,902 & H0 accepted \\
\hline
\end{tabular}

There is a difference in learning achievement in Social Studies between students with visual learning style and ones with auditory

The experimental research conducted at SMP Negeri 13 Mataram that explored the difference in learning achievement in Social Studies between students with visual learning style and those with auditory one shows a significant result. This result parallels the result of data analysis for the second hypothesis. It shows the average learning achievement of students with visual style is higher than the average of achievement of students with auditory style. The result of data analysis reveals that learning achievement of students with visual style is $\mathrm{F}$. Calculator $13.31>3.94$ value $\mathrm{F}_{\text {-Table }}$ at the degree of freedom 0.05. It is apparent that the average achievement of students with visual style is 37.20 , which is higher than the average of achievement of students with auditory style, which is 34.13 .

This result parallels with some theories that students' hereditary condition with naturally different learning styles provides opportunities for optimal achievement as long as it is optimally used and managed. DePorter (2002) argue that one's learning style function as a key to develop work performance at school and in interpersonal relationships. Although different researchers use different terms to refer to the difference in learning styles and how to deal with it, they have arguably agreed upon how to absorb information easily (modality) and how to manage and process the information (brain dominance).

Further, if learners are aware of their own learning style, they can help themselves to learn more quickly and easily. Levie (2005), based on their annotations of research findings on learning through graphic stimuli, verbal and visual, conclude that visual stimuli yield better results for tasks such as remembering, identifying, recalling, and associating facts and concepts. Baugh (2005), have a similar view in this regard. They reported that the acquisition of learning achievement through sighting and through hearing shows a very significant difference. About $90 \%$ one's learning outcome is obtained through visual sense, $5 \%$ through auditory sense, and the remaining 5\% through kinesthetic sense. Meanwhile, Dale (2005), estimated that learning happens through visual sense comprises of about $75 \%$, through auditory sense about $13 \%$, and through other senses including kinesthetic about $12 \%$. This indicates that students' learning styles are different from one another, resulting in their different potentials to absorb information. To conclude, differences in learning styles result in different learning achievements. 


\section{Implication}

As the result shows the application of multimedia results in different achievements of the students with visual and those with auditory style. This finding has an implication to the ways teachers make a decision about making use of multimedia in the classroom and to the way school manages to provide multimedia that support students learning at SMP Negeri 13 Mataram. The application of multimedia, which should be the choice for teachers in the current digital era, also needs to consider learning styles as another variance. This hereditary condition should be considered in order to create effective and efficient learning processes at school. This finding is supposed to have an impact on widening teachers' insights into educational management by making generalizations about the impacts of research variables in line with theories verified in the variant analyses.

In sum, the research findings have some implications to the side of teachers on how important for them to understand the variance of their students learning styles. The more detail the teachers have knowledge about the characteristics of their learners, the more easily they may provide treatments accordingly. The school tradition to provide an intelligence test at the beginning of the school year should provide adequate data related to students' learning styles.

The teachers' difficulties in delivering social studies lessons in integrated manners will continue to occur unless the teachers utilize multimedia in their teachings. At least the teachers should use innovative strategies and media in order to attract students' interest in learning social studies at school. Considering the complexity of social studies as an integrated course, the teachers are required to have a comprehensive understanding of the subject matter along with its composing elements.

\section{Conclusion}

Based on the research findings and discussion it can be concluded that there is a difference in the achievement of Social Studies between students with visual style and those with auditory style. It means that learning style contributes to learning achievement as a result of students, different ability in understanding the lesson or subject matter.

\section{Conflict of interest statement and funding sources}

The authors declared that they have no competing interest. The study was financed by independent funding.

Statement of authorship

The authors have a responsibility for the conception and design of the study. The authors have approved the final article.

\section{Acknowledgments}

We would like to extend our gratitude to all those who have given assistance so that this article on the critical review of the literature can be delegated. We also express our gratitude to the input and assistance of Muhammadiyah Muhammadiyah Mataram University, which has provided a forum for scientific advancement for the advancement of science, especially at the Muhammadiyah Mataram University.

Gani, A. A., Ibrahim, N., \& Khaerudin, -. (2018). Multimedia use and learning styles on learning achievement in social studies. International Journal of Social Sciences and Humanities, 2(2), 187-193. 


\section{References}

1. Astawa, I. N., Handayani, N. D., Mantra, I. B. N., \& Wardana, I. K. (2017). Writing English Language Test Items as a Learning Device: A Principle of Habit Formation Rules. International Journal of Social Sciences and Humanities (IJSSH), 1(3), 135-144.

View in (Google Scholar)

2. Baugh, J. L., \& Melenyzer, G. J. (1996). U.S. Patent No. 5,511,620. Washington, DC: U.S. Patent and Trademark Office.

View in (Google Scholar)

3. Dale, B. E., Elander, R. T., Holtzapple, M., Ladisch, M. R., \& Lee, Y. Y. (2005). Coordinated development of leading biomass pretreatment technologies. Bioresource technology, 96(18), 1959-1966.

View in (Google Scholar)

4. DePorter \& Hernacki, M. (2002). Quantum Learning: Membiasakan Belajar Nyaman dan Menyenangkan Penerjemah: Alwiyah Abdurrahman. Cetakan VII.

View in (Google Scholar)

5. Levie, J., \& Autio, E. (2008). A theoretical grounding and test of the GEM model. Small business economics, 31(3), 235-263.

View in (Google Scholar)

6. Lim, C. P., Zhao, Y., Tondeur, J., Chai, C. S., \& Chin-Chung, T. (2013). Bridging the gap: Technology trends and use of technology in schools. Journal of Educational Technology \& Society, 16(2).

View in (Google Scholar)

7. Zhao, L., Lim, S. Y., Gordon-Weeks, A. N., Tapmeier, T. T., Im, J. H., Cao, Y., ... \& Muschel, R. J. (2013). Recruitment of a myeloid cell subset (CD11b/Gr1mid) via CCL2/CCR2 promotes the development of colorectal cancer liver metastasis. Hepatology, 57(2), 829-839.

View in (Google Scholar)

8. Melvin L. Siberman, Active Learning; 101 Cara Belajar Siswa Aktif. Bandung: Nuansa Cendekia. 2014. View in (Google Scholar)

9. Sanisah (2013), Siti. Evaluasi Penggunaan Media Pembelajaran pada Mata Pelajaran IPS Jenjang SMP di Kota Mataram, Jurnal, Education Community Vol. I 0007 tahun 2013. Diakses pada tanggal 13 Juni 2015. View in (Google Scholar)

10. Silberman, M. L., \& Biech, E. (2015). Active training: A handbook of techniques, designs, case examples and tips. John Wiley \& Sons.

View in (Google Scholar)

11. Suparsa, I. N., Mantra, I. B. N., \& Widiastuti, I. A. M. S. (2017). Developing Learning Methods of Indonesian as a Foreign Language. International Journal of Social Sciences and Humanities (IJSSH), 1(2), 51-57. View in (Google Scholar)

12.Suryasa, I. W., Prayoga, I. G. P. A., \& Werdistira, I. W. A. (2018). Attitudes toward the use of internet for students. International Journal of Physical Sciences and Engineering, 2(2), 32-38.

View in (Google Scholar) 


\section{Biography of Author}

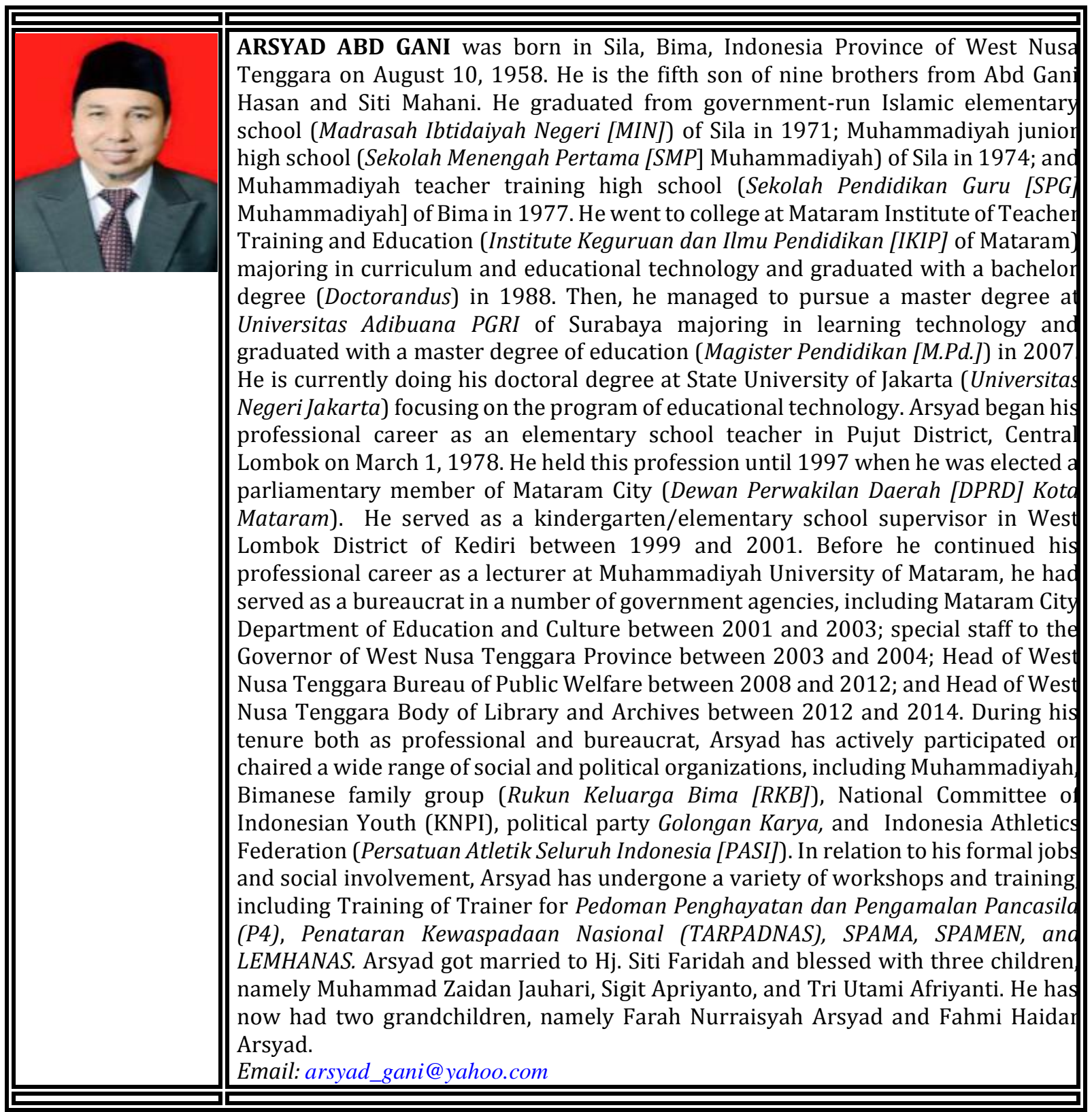

Gani, A. A., Ibrahim, N., \& Khaerudin, -. (2018). Multimedia use and learning styles on learning achievement in social studies. International Journal of Social Sciences and Humanities, 2(2), 187-193. https://doi.org/10.29332/ijssh.v2n2.163 